\title{
A Study of the Socioeconomic Determinants Associated to The Performance of the New Lands Agricultural Cooperatives at El:Behira Governorate
}

\author{
Amir Mohamed Abdalla and Amany A. El-Saied ${ }^{1}$
}

\begin{abstract}
The agricultural cooperatives play a central role in Egyptian economy, through the cooperatives roles on community development, production services, subsidized agricultural inputs, technical support, financial responsibilities and social activities. Accordingly the study aims to identifying the socioeconomic determinants of the performance of the new lands cooperatives.

The study is applying the multidimensional ILO/DANIDA scale of cooperative performance including the community development, facilitating social services, productive investment, agricultural inputs, minimizing the production cost, technical support, resources protecting, training and logistics and communication. Using he socioeconomic variables: goal attainment, self reliant ratio, marketing, annual sales, technical support, finance, training and communication.

The study was carried out on four villages at El-Behira governorate (Alghomhoria, New Edko, El-horrya and Nasser villages), and data were collected by personal interviews using a pre tested questionnaire from 155 cooperative members using a random systematic sample. The questionnaire was coded and data were statistically analyzed applying the simple correlation and multiple linear regression techniques.

The participation on cooperative activities alone explains about $17 \%$ of the variance in the cooperative performance and the values of collective work variable explains about $9 \%$ of the variance of cooperative's performance, the marketing opportunities explains about $4 \%$ of the variance in the dependent variable and the finance of productive projects variable explains about $3 \%$ $\%$ of the variance of cooperatives performance. The results were conceptualized around applied linkage that connects four practical fields; encouraging member participation, activating the values of collective work, the marketing of commercializing products and the financial support to the agricultural projects
\end{abstract}

\section{INTRODUCTION}

Agriculture remains one of the largest sectors of the Egyptian economy, accounting for about $17 \%$ of gross domestic product (GDP), 37\% of total employment, and significant foreign exchange earnings. In Egypt, the agricultural sector has been affected by many forms of government interventions, among them sector-specific policies or direct forms of intervention that include planning of the cropping pattern and rotations; procurement quotas for certain crops; fixed prices for quota and non-quota products and regulations on wholesale and retail prices; subsidization of some agricultural inputs; and an extensive consumer subsidy and rationing system for basic food items (World Bank, 2009).

In addition, economy-wide or macroeconomic and trade policies pursued by the government have indirectly affected agricultural performance. The impact of this mixed heritage of interventions is detrimental to agriculture in most developing countries, and Egypt is no exception. Sector-specific and economy-wide policies followed by the Egyptian government over the last two decades have resulted in significant negative effects on Egyptian agricultural production and exports. Policy discrimination led to imposing a substantial burden on the agricultural sector.

Moreover, these government policies have contributed to the flow of resources out of agriculture. Some experts argue that the taxation of agriculture with price and subsidy instruments has created black markets for inputs diverting subsidized inputs to profitable crops and created policy-generated rents for a few farmers, as in the case with fertilizer. Protecting certain sectors and taxing others creates inefficiencies in the allocation of scarce resources. Furthermore, exchange rate and trade policies of the Egyptian government that encouraged imports and led to a relative decline in agricultural exports contributed to significant decline in the country's self sufficiency ratios in food (World Bank, 2009).

Furthermore, the policy-makers have taken steps to reduce restrictions in the agricultural sector. Price and marketing controls over farm crops have been reduced or eliminated. In addition, some of the subsidies for farm inputs (fertilizer, animal feed, credit, pest control) were reduced.

\section{Agricultural Cooperative Movement}

The history of the cooperative movement in Egypt goes back to the beginning of this century. At that time, the Agricultural Bank of Egypt was established to provide farmers with credit. However, for the majority of the peasants, small loans were almost impossible to obtain. In 1909, the first cooperative was founded to provide credit to its members. By 1914, the number of cooperatives in the country had increased to 23 .

\footnotetext{
${ }^{1}$ Agricultural Extension and Rural Development Research Institute.

Received December8, 2010, Accepted December30, 2010.
} 
However, the lack of direct government support, the absence of legislation to organize and guide such cooperation institutions, and other financial problems were mainly responsible for the limited acceptance of the idea.

Government support for the cooperatives started in the 1920s. Several laws and decrees were passed to regulate the activities of the cooperatives. A Cooperative Department at the Ministry of Agriculture was given the authority to supervise the existing cooperative societies. The government also provided credit to cooperatives through a non-specialized bank until the Egyptian Agricultural Credit Bank was established in 1931. By the mid-1940s, there were over 2,500 cooperatives in Egypt, involving 800,000 farmers. The national network of cooperatives expanded as a result of the Land Reform Act of 1952. This law made participating in a cooperative obligatory for all beneficiaries of land reform. The main functions of these cooperatives were to provide farmers with inputs on credit; to organize and supervise cropping patterns; and to buy outputs from farmers under terms determined by the government. The cooperative functions during this period also included deducting from the revenues the price of land (Land Reform Law), land tax, agricultural loans, and other debts (ICHR, 2010).

The Egyptian Agricultural Credit Bank was nationalized in 1961. Between 1961 and 1976, the Bank dealt only with agricultural cooperatives and was not allowed to deal with individual farmers. The Bank distributed inputs to the cooperatives on credit and the cooperatives redistributed the inputs on credit to its members.

In 1976, the Bank's name was changed to the Principal Bank for Development and Agricultural Credit (PBDAC). 1976 Law No. 117 was issued to establish village banks and to allow PBDAC to deal with individual farmers. PBDAC took over all storage facilities of the agricultural cooperatives and their offices.

Supervision of cropping patterns and estimating farmer's needs of agricultural inputs were the only functions left for the agricultural cooperatives after 1976. The Government passed another law in 1980 (Law No. 122) to organize all types of agricultural cooperatives in Egypt. The 1980 law provided the cooperatives with the power to restore their ownership of storage facilities and their function of distributing agricultural inputs with a 5\% commission. Recently the total number of agricultural cooperatives in Egypt was estimated at 6,419 cooperatives (ICHR, 2010).

The structure of agricultural cooperative in Egypt takes a pyramidal shape with a three federal systems, whereas the central agricultural cooperative union is at the top of the agricultural cooperative structure which includes Land Reclamation Cooperatives (440), Land Reform Cooperatives (779), and some 5,200 under the Agricultural Credit Cooperative System. It is organized at three different levels, consisting of the National Agricultural Cooperative Federation and central cooperatives at regional level and cooperatives at local level. Looking back at the early years in cooperative movement history, one can identify the absence of government involvement and support as one of the major causes of its limited success during those years (USAD, 2009).

However, in the last four decades the government has used cooperatives to implement agricultural policies. Government control has limited effective popular participation, the corner-stone of any cooperative organization. The effects of too much government intervention in the cooperative movement on the agricultural sector of Egypt were in the most part negative. As early as 1969, the Institute of National Planning published a critique of cooperatives, accusing them of interfering with private marketing, bureaucratic abuses, and of being used by the government for fiscal purposes. Intervention and controls were viewed merely as distortions to agricultural incentives, leading to loss of income for farmers (USAD, 2009).

\section{New lands cooperatives}

The Egyptian governments have undertaken an extensive program to reclaim desert lands as part of the initiative strategy to put an end to Egypt's dependence on foreign countries". Top priority is placed on reclaiming desert lands for agricultural cultivation at an average rate of no less than 150,000 feddans annually. Since 1954, approximately 2.4 million feddan have been added to Egypt's cultivated area. Approximately 1.2 million feddans have been reclaimed in the decade between 1985:1995 and to date, the surface area of cultivable desert lands comes to approximately 3 million feddans (IFAD, 2008)..

Egypt's current 1992-1997 Five-Year-Plan for land reclamation calls for reclaiming an area of 827,000 feddan in desert areas east and west of Egypt's Nile Valley. Approximately one-third of the land reclaimed will be parceled to graduates of universities and higher vocational secondary schools. Of these 10,000 graduates, about $40 \%$ are expected to have formal academic qualifications in agriculture, while others will have completed courses in non-agricultural fields of study.

The new settlers receive basic housing and essential services in villages planned for 500-1,000 households. These villages are served by roads and provided with an infrastructure for schools, health facilities, mosques and 
facilities for the provision of community, economic and agricultural support-services delivering by cooperatives. Program implementation focuses on agricultural/rural development, agri-technology, business administration, community planning, computer sciences, entrepreneurship and small business development training (IFAD, 2008).

To successfully accomplish the development goals designated by Egypt's General Authority for Rehabilitation Projects and Agricultural Development (GARPAD), rural development is undertaken within a comprehensive framework which integrates agricultural activity with other aspects of economic and social life. This approach promotes the successful reclamation of vast desert areas, not only from the standpoint of agricultural production, but from the standpoint of the broader socio-economic goals inherent in the program to resettle university graduates as well.

The impact of agrarian reform programs in Egypt has been positive. The agrarian sector is becoming increasingly more liberalized and oriented toward free market mechanisms. The result of present policies has been impressive gains in output, with grain crops reaching record levels in the mid-1990s. Significant achievements towards furthering Egypt's self sufficiency have been attained and exports for several crops have grown over the last few years. In 1994, agricultural production increased by approximately $2.5 \%$, in spite of unusually insensitive weather conditions (FAO, 2007)

\section{Theoretical Background}

From a sociological perspective, there exist some conceptual and practical dilemmas that occur within the theory and practice of the cooperative movement and cooperative organizations that define differing orientations between the social and economic theorists of cooperation. They include: 1) meaning versus service, 2) efficiency versus democracy, and 3) bureaucratic logic versus cooperative logic. At least three purposes of economic organizations can be identified; respectively, making profits, providing services, and realizing meaning. Their predominance and mix tend to vary both across and within organizations (Staatz, 1983).

Social organizations tend to range along a continuum from investment oriented firms (IOFs) at the profits end to the social organization at the community services end . Cooperative organizations can be found at different locations on the continuum, with a predominance located within the service purpose, i.e. a focus on serving the greatest numbers of people over the longest period of time. Most farm input and service cooperatives fall into this spot on the continuum. Agricultural marketing cooperatives tend to be found between the service and profit purpose orientation, with new generation cooperatives attempting to preserve earnings benefits for defined membership over time. The life meaning purpose at the other end of the continuum gives much greater focus to participation and democratic process. Cooperative organizations typically contain elements of all three of these tendencies (Craig, 1993).

In short there are several interrelated polemic themes that emerge out of the philosophy and theory of cooperation and the cooperative movement; as well as from the practice of cooperation as realized in organizations functioning to meet internal goals within a socio-economy. Organization for service or meaning/participation is a central dilemma that is found internationally. The predominance of each tendency varies across types of cooperative organizations as well as within organizations. North American agricultural input cooperatives are primarily service cooperatives, while conventional agricultural marketing cooperatives have a service orientation but with an increased emphasis on earnings. Given a competitive market place, efficiency criteria tend to drive organizational form toward bureaucratic models, and paradoxically away from cooperative logic form. When participation declines and organizations tend toward greater centralization of decision making (bureaucratic logic), it becomes increasingly difficult to recognize differences in cooperative behavior from investor oriented firm behavior ( IOF) and cooperative character can be lost. However, to act without recognition of market imperatives (need for earnings) can also result in the loss of cooperative presence (Rhodes, 1983).

This dilemma explains in large measure the root differences between the social and economic philosophies of cooperation. Social philosophers emphasize democratic control in the form of one-person, one-vote as the cardinal principle of cooperation (Lambert, 1963). Economic philosophers on the other hand emphasize the distribution of benefits in proportion to use as the cardinal principle. These differences have been frequently articulated by cooperative leaders like Voorhis (1975), who feel the service and participatory end of the continuum, are lost in cooperatives that strictly advocate a "bottom line" orientation (Voorhis, 1975).

\section{Aim of the Study}

The main objective of this study is to examine the relationship between socioeconomic determinants and the performance of agricultural new lands cooperatives at Elbehira governorate. 


\section{METHODOLOGICAL PROCEDURES}

Sampling Design: The study was performed to explore the socio-economic determinants of the performance of the new land cooperatives . Elbehira governorate has 2 cooperative control authorities: 1- the North of Elbehira has 4 cooperative regions; Eldoshody, Edko, Elbostan/ferhash and North El-tahrir) and 2:- the southlwest Eltahrir has 3 cooperative regions Altahddy, alganouby and Alfath), accordingly the study focuses into the control authority North of Elbehira as presented at table (1).

The Elbehira governorate was represented through 4 villages; whereas the Alghomhoria, New Edko, Elhorrya and Nasser villages were selected randomly to represent the entire cooperatives at Elbehira governorate. The studied sample includes $20 \%$ of cooperative members from the complete list of selected 4 villages; systematic random sample was applied to verify the selected members, specifically; 48 members from Alghomhoria village, 31 members from New Edko village, 50 members from El-horrya village and 26 members from Nasser village, therefore the studied sample consist of 155 members from 4 selected cooperatives.

Measurements: The study exploited the performance of the new land cooperatives as dependent variable and socio-economic determinants are representing 10 independent variables:

The dependent variable: The performance of the new land cooperatives was measured by using of the scale of ILO and DANIDA is formulating the cooperative performance as presented (ILO,1997):

1-Community development indicators: clean water, electricity, drainage, housing, food supply (5 items).

2-Facilitating the social organization services (local unit, extension center, local community unit, health unit and governmental organizations.)

3-Agricultural activities of productive investment

4-Availability of agricultural inputs.

5-Minimizing the production cost of agricultural production.

6-Technical support.

Table 1. The distribution of sampling frame
7-Protecting of cooperatives resources (lands improvement, water rational utilization, modern water irrigation systems, desalination programs and land quality adjustment)

8-Training and skills improvement of their members.

9-Logistics and communication (ILO,1997)

The variable of performance of the new land cooperatives was measured by : the evaluation of progress at last three years, and 6 answers were designed as follows ; (no progress), (the progress was less than $10 \%$ ), ( from $10 \%$ to $20 \%$ ), ( from $20 \%$ to $30 \%$ ), (from $40 \%$ to $50 \%$ ), ( more than $50 \%$ ), weighed from 1 to 6 respectively.

Socio- economic determinants: the independent variables include both economic and social determinants, the measurements of all independent variables were appraised as addressed:

\section{Economic indicators:}

1- Sales growth.

Sales growth was measured by one question includes 4 items as follows:

The agriculture cooperative helps me to enlarge my sales; regarding: the traditional crops- livestock- fruitsfood products.

2- Annual net profit.

Annual net profit was measured by one question includes 3 items as follows:

The net profit $=$ total sales- the total costs.

3- Self reliance ratio.

Self reliance ratio was measured by one question calculates both the annual purchases divided into two items the value of cooperative purchases and the value of total annual purchases, whereas self reliance ratio $=$ the value of cooperative purchases the value of total annual purchases* 100.

4- Marketing opportunities.

Marketing opportunities was measured by one question includes 1 item as follows:

The cooperative supports me to expand the marketing opportunities and chances.

\begin{tabular}{clcc}
\hline & \multicolumn{1}{c}{ The cooperative regions } & Population & Sample \\
\hline 1 & Eldoshody: Alghomhoria village & 242 members & 48 members \\
\hline 2 & Edko, New Edko village & 154 & 31 \\
\hline 3 & Elbostan/ferhash,: El horrya village & 248 & 50 \\
\hline 4 & North El-tahrir: Nasser village & 132 & 26 \\
\hline Total & & \multicolumn{2}{c}{$\mathbf{1 5 5}$ members } \\
\hline
\end{tabular}


5- Finance of productive projects.

The finance of productive projects was measured by one question includes 6 items as follows: the cooperative assists their members to finance:

1- The industrial projects (such as parts of agricultural machinery, tractors, water motors) ,2- the agricultural projects (such as untraditional animal fodders, compost, organic fertilizers,) ,3- commercial projects (such as collective marketing entities, local trading points), 4- the secondary services projects (such as transportation services, storage, grading, containing and packaging projects) 5- sales units (such as agricultural sales units, exporting points, local and regional agricultural exhibitions) and 6- small business projects (such as dairy, food production, poultry and veterinary projects)

\section{Social indicators:}

6- The attitudes towards the cooperative.

The attitudes towards the cooperative variable was measured by one question includes 4 items regarding: athe acceptance of cooperative services b- the motivation to work with the cooperative, $\mathrm{c}$ - the appreciation of the cooperative activities and $\mathrm{d}$ - the willingness of continuing the participation with cooperative on future.

7- The trust of cooperative board.

The trust of cooperative board was measured by one question includes 4 items regarding: a- the conviction of the board members skills and abilities ,b- the trust of board's agricultural experiences, c- the confidence of the decision making process, $d$ - the trust of board's pureness honesty and rightness.

8- The participation in cooperative activities.

The participation in cooperative activities was measured by one question includes 4 items as follows: athe contribution in cooperative activities by physical efforts, b- the involvement in cooperative problem, difficulties and barriers, $c-$ the financial sharing, $d-$ the participation in consulting and advises.

9- The values of collective work.

The values of collective work was measured by one question includes 4 items: a- the perception of we and togetherness, b- the awareness of the cooperation concept, c- the perception of the positive outcomes of

Table 2. The frequency of cooperatives performance

\begin{tabular}{lcc}
\hline & frequency & \% \\
\hline Low performance (lowest than 60 points) & 57 & 37 \\
\hline Moderate performance (from 60 to 75 points) & 74 & 48 \\
\hline High performance (highest than 75 points) & 24 & 15 \\
\hline Total & $\mathbf{1 5 5}$ members & $\mathbf{1 0 0 \%}$ \\
\hline
\end{tabular}

collective work, $d$ - the value of inter- independency and integrity with others.

10- The social acceptance of cooperative activities.

The variable of social acceptance of cooperative activities was measured by one question includes 5 items: a- the local understanding the plans and programs of cooperative board, b- the approving from local population, c- the social consensus concerning the judgments of cooperative board , $\mathrm{d}$ - the local acceptance of board's decisions, $\mathrm{f}-$ the support of local leaders.

The all items of independent variables were measured by formulated answers; strongly agree, agree, neutral, disagree and strongly disagree, weighed from 5 to 1 respectively.

Data collecting: The secondary data was collected form the administrative records of governmental authorities. And the questionnaires were pre-tested and collected by personal interviews from the cooperatives members at July 2010.

\section{Reliability Assessment:}

Alpha Chronbach coefficient was applied to estimate the reliability of studied dependent variable (cooperative performance), and the results showed that alpha values was 0.816 which revealed the reliability and the internal consistency between the studied sub-dimensions of the cooperative performance (dependent variable).

\section{RESULTS AND DISCUSSION}

The descriptive analysis for the cooperatives $37 \%$ from the studied sample) was addressing that the cooperatives performance is low, the cooperatives performance for 74 members $(48 \%)$ was moderate, and 24 members (representing 37\% from the studied sample) was clarifying that the cooperatives performance is ultimately high table (2). The cooperatives performance of the majority of studied members is addressed between the low and moderate performance which is revealing the need to an integrated action plans to develop the current organizational and social barriers and obstacles.

r Pearson correlation coefficient was applied to detect the direction and relationship between the cooperative performance and the socioeconomic variables, As figured at table (3) the relationship between cooperative performance is revealing that 57 members (representing productivity and to overcome the economic, 
performance and marketing opportunities, finance of productive projects, participation on cooperative activities and the values of collective work were significant at 0.01 level whereas the $r$ value were 0.208 , $0.344,0.357$ and 0.226 respectively, and the relationship between cooperative performance and The social acceptance of cooperative activities was significant at 0.05 level whereas the $r$ value was 0.204. The mentioned result is highlighting the cooperatives roles towards the trading activities and exploring new markets, to sustain the needed budgets to finance the productive projects of their members economically and to activate the participation of those members on cooperative activities, to stimulate values of collective work and finally to assure the social support of cooperative activities.

Multiple linear regression was conducted to predict the explained variance of the cooperatives performance (dependent variable) based on some predictors (independent variables). As showed in table (4) multiple correlation coefficient was 0.594 and $F$ value 17.871 (significant at 0.01 ) and $\mathrm{R}$ square value was 0.353 meaning that the studied independent variables explain about $35 \%$ from the variance of cooperatives performance (as dependent variable).

Table 3. The relationship bet
As figured at table (4) the standardized coefficients (Beta) of participation in cooperative activities and the values of collective work were positive and significant at 0.01 whereas $t$ values were 4.712 and 5.359 respectively. The standardized coefficients (Beta) of marketing opportunities and finance of productive projects were positive and significant at 0.05 , whereas $t$ value was 2.083 and 2.279 respectively.

Stepwise multiple regression model yielded a reduced equation containing 4 variables and explains 33\% from the variance of cooperatives performance (as dependent variable) and the six variables were excluded from the equation (sales growth, annual net profit, self reliance ratio, the attitudes towards the cooperative, the trust of cooperative board, the social acceptance of cooperative activities and the social acceptance of cooperative activities). Table (5) clarified that multiple correlation coefficient was 0.571 and $F$ value 18.137 and it's significant at 0.01 , and $\mathrm{R}$ square value was 0.326 which means that the participation in cooperative activities, the values of collective work, marketing opportunities and finance of productive projects (as independent variables) explain $33 \%$ from the variance of cooperatives performance (as dependent variable).

\begin{tabular}{lcc} 
Table 3. The relationship between the cooperatives performance and independent variables \\
\hline \multicolumn{1}{c}{ Variable } & r Pearson value & Sig. \\
\hline X1 Sales growth & 0.049 & 0.548 \\
\hline X2 Annual net profit & 0.145 & 0.071 \\
\hline X3 Self reliance ratio & 0.153 & 0.056 \\
\hline X4 Marketing opportunities & $0.208^{* *}$ & 0.009 \\
\hline X5 Finance of productive projects & $0.344^{* *}$ & 0.000 \\
\hline X6 The attitudes towards the cooperative & 0.030 & 0.628 \\
\hline X7 The trust of cooperative board & 0.104 & 0.197 \\
\hline X8 The participation in cooperative activities & $0.357^{* *}$ & 0.000 \\
\hline X9 The values of collective work & $0.226^{* *}$ & 0.005 \\
\hline X10 The social acceptance of cooperative activities & $0.204^{*}$ & 0.011 \\
\hline$*$ correlation is significant at the 0.01 level & & \\
: correlation is significant at the 0.05 level & &
\end{tabular}

Table 4. Multiple linear regression results

\begin{tabular}{lccc}
\hline \multicolumn{1}{c}{ Variable } & Beta & t value & Sig. \\
\hline X1 Sales growth & 0.049 & 0.763 & 0.423 \\
\hline X2 Annual net profit & 0.145 & 1.078 & 0.238 \\
\hline X3 Self reliance ratio & 0.153 & 1.350 & 0.179 \\
\hline X4 Marketing opportunities & 0.208 & 2.083 & 0.039 \\
\hline X5 Finance of productive projects & 0.344 & 2.279 & 0.024 \\
\hline X6 The attitudes towards the cooperative & 0.030 & 1.174 & 0.076 \\
\hline X7 The trust of cooperative board & 0.104 & 0.890 & 0.357 \\
\hline X8 The participation on cooperative activities & 0.357 & 4.712 & 0.000 \\
\hline X9 The values of collective work & 0.226 & 5.359 & 0.000 \\
\hline X10 The social acceptance of cooperative activities & 0.204 & 0.211 & 0.801 \\
\hline
\end{tabular}

$i=17.871^{* *}$

Multiple correlation coefficient $=0.594$

? square $=0.353$ 
Table 5. The stepwise multiple regression analysis

\begin{tabular}{lccccc}
\hline \multicolumn{1}{c}{ Independent Variables } & Beta & t value & Sig. & \multicolumn{2}{c}{ R square } \\
\cline { 5 - 6 } & & & & change & accumulation \\
\hline X8 The participation in cooperative activities & 1.378 & 5.908 & 0.000 & 0.168 & 0.168 \\
\hline X9 The values of collective work & 1.201 & 5.006 & 0.000 & 0.261 & 0.093 \\
\hline X4 Marketing opportunities & 0.732 & 2.576 & 0.011 & 0.299 & 0.038 \\
\hline X5 Finance of productive projects & 0.508 & 2.501 & 0.017 & 0.326 & 0.027 \\
\hline
\end{tabular}

$\mathrm{F}=18.137$

Multiple correlation coefficient $=0.571$

The independent variables were ranked as follows: firstly the participation in cooperative activities alone explains about $17 \%$ of the variance in the dependent variable and the values of collective work variable explains about $9 \%$ of the variance of cooperatives performance (as a dependent variable). Thirdly the marketing opportunities explains about $4 \%$ of the variance in the dependent variable and fourthly finance of productive projects variable explains about $3 \%$ of the variance of cooperatives performance.

\section{CONCLUSION}

Like those of other nonprofit organizations, agricultural cooperatives in new lands are now confronting new emerging needs and challenges from members and markets caused by national and global changes in the $21^{\text {st }}$ century. Cooperative members want not only to sell their products as fast as possible but also with high economic returns. Thus, it becomes the responsibility of the cooperatives to assist their members not only in selling their products but also at good prices. Furthermore, the new market economics in which agricultural cooperatives operate bring about new types of consumers who demand high-quality products at reasonable prices, and prefer healthy and chemical-free food at international standards. They want to know the origin of the foods they buy, and whether they are grown through socially acceptable and environment-friendly methods. These phenomena offer both new opportunities and also threats to agricultural cooperatives.

Although most of agricultural cooperatives in new lands remain confined to their main functions like distribution of credit and fertilizers, and procurement of farm products, some changes and modifications should be designed at agricultural cooperatives to transform themselves and implement new strategies in this new economic environment. The innovative practices as a new direction of agricultural cooperatives in new lands are as follows:

-Responding to the needs of the members', cooperative problems, production priorities, decision making thereby encouraging member participation.

-Activate the values of collective work between cooperative members throughout the shared benefits, cooperated production, minimizing costs, reducing risks and collective responsibilities.

-Cooperative commerce and use of collective production. Cooperative commerce is a new way of commercializing products. It offers marketing of products and services via shared negotiation, exploring new markets and by using the e-marketing tools.

-Providing technical support in areas of marketing and supply.

-Enhancing higher economic returns to members through value-addition.

-Offering a high level of market information enabling better business decisions.

-Provide financial support to the productive projects (industrial, agricultural, commercial, secondary services \{transportation, storage, grading and containing, packaging s sales units and small business projects).

\section{REFERENCES}

Craig, John G., The Nature of Cooperation, Black Rose Books, 1993.

FAO, The setting up of land reclamation, (2007), volume 3, Rome.

IFAD. Land Use and Farming Systems, Middle east office, (2008), Cairo.

ICHR .Agriculture cooperatives in Egypt; New concept, Land center for human rights, (ICHR), Cairo, (2010).

(ILO) The International Labor Organization. the declaration of principles concerning multinational enterprises and agricultural cooperatives. The DANIDA Guidelines for social policy (1997).

Lambert, Paul, Studies in the Social Philosophy of Cooperation, Cooperative League of the U.S.A., (1963).

Rhodes, V. James. "Cooperatives and Contestable/Sustainable Markets." (1983)

Staatz, John M. "The Cooperative as a Coalition: A GameTheoretic Approach." American Journal of Agricultural Economics 65(1983):1083-89.

USDA. The Future of cooperatives: How Today's Economic Forces Shape Tomorrow's World, (2007): 1, USDA.

Voorhis, Jerry. Cooperative Enterprise, Interstate Printers and Publishers, (1975).

World Bank, Egypt: the development measurements, (2009). 


\section{الملخص العربي \\ دراسة المحددات الاجتماعية والاقتصادية المرتبطة بكفاءة التعاونيات الزراعية للاراضى المستصحلة بححافظة البحيرة \\ أمير مُعْمَّم عبدالله، أمانى عبد المنعم السيد}

الجمعيات التعاونية تم اختيارهم بطريقة عشوائية منتظمة، (الجمهورية وادكو الجديدة والحرية وناصر)، حيث تم جمع البيانات وقد تم مراجعة

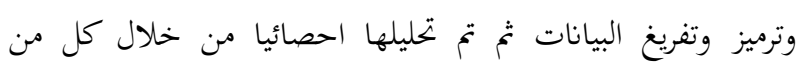
الارتباط البسيط والانحدار الخطى المتعدد.

وقد أوضحت نتائج الدراسه أن متغير مشاركة الاعضاء في انشطة

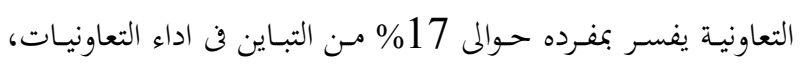

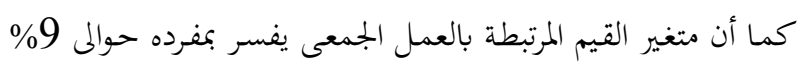

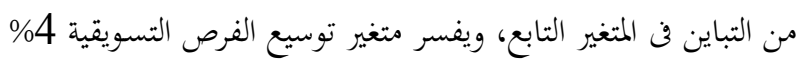

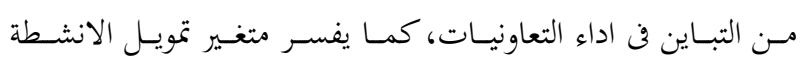

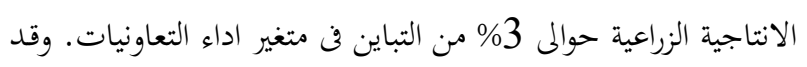
تم وضع نتائج الدراسه فن إطار عمل تطبيقى يربط بين اربعة ميادين:

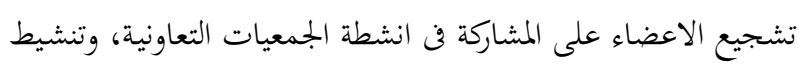

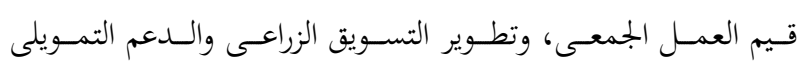
للمشروعات الانتاجية الزراعية.
تلعب الجمعيات التعاونية الزراعية دورا مركزيا في الاقتصاد المصرى وذلك عن طريق مجموع ادوارها في كل من تنمية المجتمعات المحلية

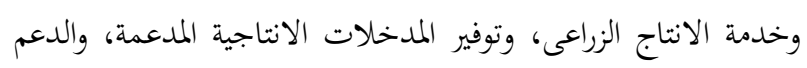

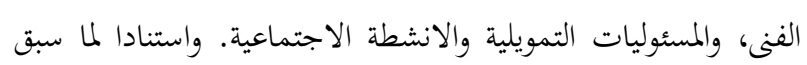
تحدف الدراسة الى التعرف على المحددات الاقتصادية الاجتماعية المرتبطة بأداء التعاونيات الزراعية في الاراضى المستصلحة.

وقد اعتمدت الدراسة على مقياس ILO/DANIDA المتعدد الابعاد لقياس اداء تعاونيات الاراضى المستصلحة حيث يتضمن ابعاد

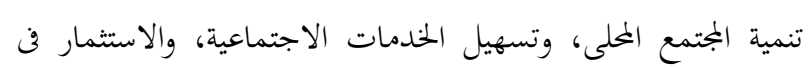

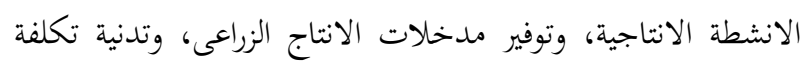

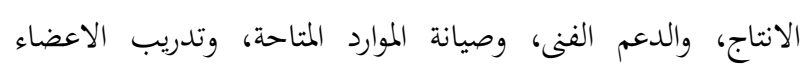
والاتصال والدعم اللوجيستى. وقد اجريت الدراسة في اربعة قرى بمحافظة البحيرة بواسطة

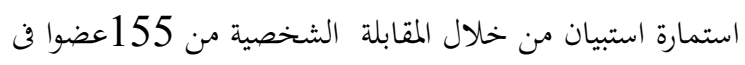

